
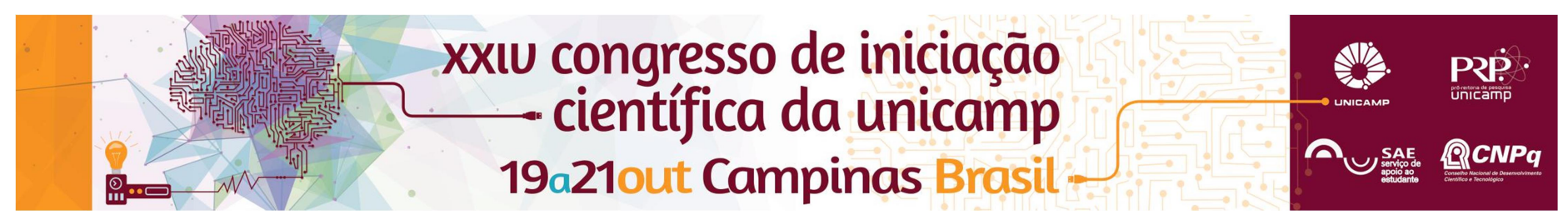

\title{
Management of subirrigation benches in the production of sugarcane seedlings.
}

\section{Fernando H. L. Rodrigues*, Edson E. Matsura.}

\begin{abstract}
The use of a closed water system allows the remaining solution to return by gravity to a reservoir, where the water can be evaluated for reuse, increasing the efficiency of resources and inputs as well as preventing soil contamination and waste of water ${ }^{1}$. The objective is to evaluate the application of the subirrigation technique in the sugarcane seedlings production, using humidity capacitive sensors to control and to automate the irrigation in the subirrigation bench.
\end{abstract}

\section{Key words:}

Irrigation, Protected Environment, Sugarcane.

\section{Introduction}

One of the most common means of production using subirrigation in a protected environment is the ebb-andflow, in which the substrates are used as a path for capillarity and the plants get their roots wet.

The production potential of sugarcane seedlings consists in reducing the volume of sugarcane used to crop and better quality control which increase the product's homogeneity ${ }^{2}$.

Developing techniques that improve or benefit the use of the MPB technology can provide upgrades in natural resources saving, like water and the sugarcane itself.

\section{Results and Discussion}

In order to know the dynamics of the moisture in the substrate in contact with water, it was built a set of tubes containing substrate and a humidity sensor to reproduce the conditions of the subirrigation table.

Reproducing the functioning principle of the subirrigation, six different heights of water were applied, from $1 \mathrm{~cm}$ to 6 $\mathrm{cm}$, and every value of humidity read by the sensors inside the tubes had made possible an study of the moisture behaviour (see Image 1).

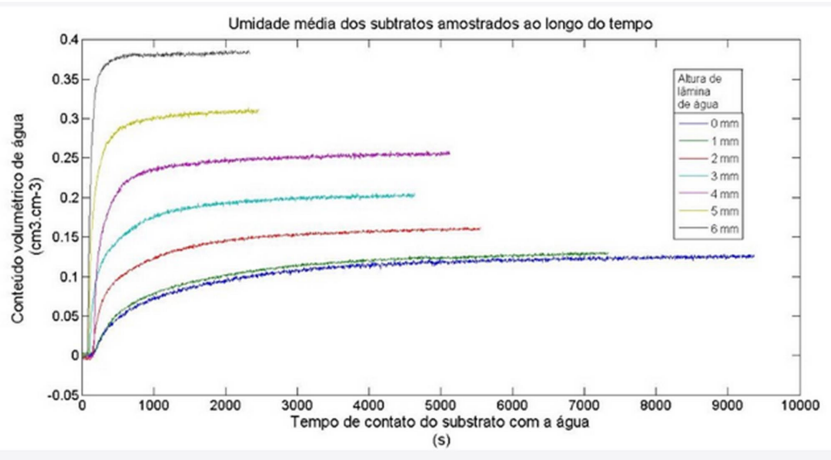

Image 1. The mean humidity (\%) for each different height over time (s).

The laboratorial tests indicates that the higher the water, the faster and greater the moisture got.

It was possible to describe this phenomenon using some equations. Supposing those obtained curves could be described by first order transfer functions (Equation 1), the time constants (Equation. 2) and the gains (Equation. 3 ) of these functions were calculated for each value of water height, having those variables described in function of the height $(x)$, enabling the calculation of a transfer function for any height desired.

$\mathrm{G}(\mathrm{s})=\mathrm{K} /\left(\mathrm{T}^{*} \mathrm{~s}+1\right)$. Equation 1

$\mathrm{T}=(1 / 4)^{\star}\left(1,19 \mathrm{x}^{2}+\mathrm{x}(-162,85)+5861\right)$ Equation 2

$K=0,023 e(-0,1251 x)+0,006 e(0,0007 x)$ Equation 3

The experiments for the real situation, in a greenhouse with subirrigation benches, are still ocurring.

\section{Conclusions}

The model provided necessary information to assist in the decisions for the irrigation management. The knowledge of the system dynamics enables the estimation of equipment parameters, important in the structure design stage. This study will also serve as a basis for future strategies to be adopted in the project.

\section{Acknowledgement}

I would like to express my thanks to my Professor Dr. Edson E. Matsura and my research and work companion Thomaz Penteado for all the support.

I specially thank FAPESP for funding this project.

\footnotetext{
${ }^{1}$ DUMROESE, R. K. et al. Subirrigation: Reduces Water Use, Nitrogen Loss, and Moss Growth in a Container Nursery. Native Plants Journal, v. 7, n. 3, p. 253-261, 2006.

${ }^{2}$ XAVIER, M. A. et al. Fatores de Desuniformidade e Kit de Pré-Brotação IAC para Sistema de Multiplicação de Cana-de-Açúcar - Mudas Pré-Brotadas ( MPB ). 2014.
} 